\title{
Perbedaan Faktor Predisposisi Cara Buang Air Besar pada Kampung Belum ODF dan Kampung ODF di Surabaya
}

\section{Differences of Predisposition Factors on Ways of Defecation in Non- ODF Village and ODF Village in Surabaya}

\author{
Bening Kusuma Ramadhini*1 ${ }^{1}$, Putri Nabilah Ramadhani ${ }^{1}$
}

\begin{abstract}
ABSTRAK
Latar Belakang: Cara buang air besar merupakan suatu perilaku yang dianggap baik jika seseorang melakukannya dengan benar yaitu di jamban namun, kenyataanya masih banyak masyarakat di perkotaan yang masih melakukan kebiasaan buang air besar sembarangan (BABS). Kebiasaan tersebut dipengaruhi oleh adanya faktor predisposisi dari masing-masing individu yang terdiri dari sikap dan pengetahuan.

Tujuan: Penelitian ini bertujuan untuk mengetahui perbedaan faktor predisposisi terhadap cara buang air besar pada kampung belum ODF dan kampung ODF di Surabaya.

Metode: Penelitian ini merupakan observasional analitik dengan desain penelitian cross sectional. Populasi penelitian yaitu seluruh masyarakat yang tinggal di Kampung belum ODF di Kelurahan Jagir terdiri dari 3 RT pada RW 10 sebanyak 215 KK dan kampung ODF di Kelurahan Ketintang terdiri dari 2 RT pada RW 3 sebanyak 147 KK. Besar sampel dihitung menggunakan rumus Slovin didapatkan sebanyak 68 responden di kampung belum ODF dan 60 responden di kampung ODF. Data primer bersumber dari wawancara berdasarkan kuesioner dan data sekunder dari profil masing-masing kelurahan. Data dianalisis menggunakan uji Mann- Whitney U test.

Hasil: Hasil dari penelitian ini didapatkan adanya berbedaan sikap $(\mathrm{p}=0,00)$ dan pengetahuan $(\mathrm{p}=0,00)$ terhadap cara buang air besar pada kampung belum ODF dan kampung ODF.

Kesimpulan: Terdapat perbedaan faktor predisposisi terhadap cara buang air besar masyarakat di kampung belum ODF dan kampung ODF. Penelitian ini menyarakan untuk melaksanakan penyuluhan terkait cara buang air besar yang baik.
\end{abstract}

Kata kunci: sikap, pengetahuan, cara buang air besar

\begin{abstract}
Background: How to defecate is good behaviour if someone does it in the lavatory. However, there are stillmany people in urban areas who still practice open defecation (BABS). This habit obtained from the presence of predisposing factors from each individual consisting of attitudes and knowledge.

Objectives: This study aims to look at the peaceful predisposing factors for defecating in non-ODF and ODF villages in Surabaya.

Methods: This study was an observational analytic study with a cross-sectional design. The study population was all people who live in non-ODF Villages in Jagir Village consisting of 3 RT in RW 10 of 215 families and ODF Villages in Ketintang Village consisting of 2 RT in RW 3 of 147 families. The sample size calculated using the Slovin formula. It found that 68 in non-ODF villages and 60 respondents in ODF villages. Primary data sourced from interviews based on questionnaires, and secondary data got from the sub-district profile. Datawere analyzed using the Mann-Whitney U test.

Results: This study found that there were different attitudes $(p=0.00)$ and knowledge $(p=0.00)$ on how to defecate in villages that were non-ODF villages and ODF villages.

Conclusions: There are differences in predisposing factors for defecating in communities not yet ODF and in ODF villages. This research suggests carrying out education related to suitable defecation methods.
\end{abstract}




\begin{abstract}
*Koresponden:
bening.kusuma.ramadhini-

2016@fkm.unair.ac.idBening Kusuma

Ramadhini

${ }^{1}$ Departemen Kesehatan Lingkungan, Fakultas Kesehatan Masyarakat, Universitas Airlangga,

Kampus CMulyorejo, 60115, Surabaya, Jawa Timur, Indonesia
\end{abstract}

\title{
PENDAHULUAN
}

Status kesehatan yang baik dipengaruhi oleh kondisi lingkungan yang baik. Pembuangan tinja, perumahan, ketersediaan air besih, pembuangan sampah, pembuangan air limbah, dan kandang hewan ternak merupakan lingkup dari kesehatan lingkungan (Notoatmodjo, 2012). Suatu upaya dalam meningkatkan derajat kesehatan salah satunya yaitu dengan diadakannya sarana lingkungan fisik seperti jamban keluarga. Kebiasaan Buang Air Besar Sembarangan (BABS) merupakan kegiatan membuang tinja di hutan, sungai, ladang, semak- semak, dan area yang terbuka lainnya sehingga apabila dibiarkan dapat mengkontaminasi udara, air, tanah, dan lingkungan sekitar yang dapat menimbulkan masalah baru dan berbahaya bagi manusia (WHO and UNICEF, 2017). Masyarakat masih banyak yang memiliki kebiasaann buruk yaitu dengan BABS di sungai, kolam ikan lele, dan beberapa masyarakat yang mengalirkan tinjanya ke kolam lele serta masih terdapat masyarakat yang menumpang untuk Buang Air Besar (BAB) yang sudah menjadi budaya (Widowati, 2015).

Kebiasaan yang higienis salah satunya yaitu dengan kebiasaan buang air besar. Buang air besar yang baik dan benar yaitu apabila masyarakat melakukannya di jamban yang dilengkapi dengan pengolah feses, baik secara individu maupun komunal. Faktor predisposisi yang terdiri dari sikap, niat, pengetahuan, dan kebiasaan masyarakat merupakan faktor yang dapat mempengaruhi kebiasaan masyarakat dalam buang air besar (Syam, 2020). Peraturan Menteri Kesehatan Nomor 3 Tahun 2014 tentang Sanitasi Total Berbasis Masyarakat (STBM), merupakan suatu pendekatan yang berfungsi sebagai pengubah perilaku sanitasi dan higienis pada masyarakat melalui suatu metode pemicuan. Fokus dari STBM sendiri yaitu supply improvement, demand creation, dan enabling environment.

Masyarakat dunia sebesar 15\% atau sekitar 1,04 milyar masih buang air besar di ruang terbuka dan Indonesia menempati nomor urut 2 dari 10 negara yang dijadikan penelitian. Angka capaian Jawa Timur mengenai penggunaan jamban sebesar $85 \%$ dan naik sekitar 3\% dari hasil survey yang dilakukan pada tahun 2013 (Kementerian Kesehatan RI Badan Penelitian dan Pengembangan, 2018). Sanitasi Total Berbasis Masyarakat (STBM) merupakan suatu pendekatan yang seringkali digunakan dari banyak negara. Sebanyak 11 kabupaten/kota di Jawa Timur dari 38 kabupaten/kota menyatakan wilayahnya sebagai predikat Open Defecation Free (ODF) yaitu Batu, Magetan, Madiun, Kediri, Banyuwangi, Lamongan, Malang, Pacitan, Blitar, Pamekasan, dan Ngawi. Akses sanitasi setiap tahunnya mengalami peningkatan sekitar 2-3\% (Kemenkes, 2019).

Surabaya merupakan kota metropolitan yang masih belum menyatakan wilayahnya sebagai ODF. Surabaya memiliki 7 kecamatan yang menyatakan 100\% ODF dan 7 kecamatan masih belum terdapat verifikasi terkait ODF. Kecamatan Wonokromo tepatnya di Kelurahan Jagir merupakan salah satu lokasi yang paling rendah terkait akses jamban sebesar 94,57\%. Penduduk Kecamatan Wonokromo yang masih memiliki kebiasaan OD dan menumpang untuk BAB menggunakan jamban sehat sebanyak 1.214 Kepala Keluarga (KK), 48.930 KK memiliki Jamban Sehat Permanen (JSP), dan status Jamban Sehat Semi Permanen (JSSP) sebanyak 1.440 KK (Kemenkes, 2019).

Kelurahan Jagir terdapat pemukiman yang kumuh dan kurang memperhatikan lingkungan terutama yang terletak di pinggir rel kereta api. Peneliti memilih lokasi tersebut sebagai kampung belum ODF untuk penelitian dan dibandingkan dengan kampung ODF. Kampung ODF terletak pada Kelurahan Ketintang, yang mana lokasi tersebut sudah berstatus ODF. Lokasi Kelurahan Ketintang hampir sama dengan Kelurahan Jagir bertempat di pinggir rel kereta api dengan pemukiman yang kumuh.

Hasil survey pendahuluan, masih banyak masyarakat Surabaya yang masih melakukan BABS dan belum mempunyai jamban. Hal tersebut dikarenakan kurangnya pengetahuan dan informasi sehingga masih banyak masyarakat di perkotaan yang melakukan BABS. Perilaku BABS masyarakat tersebut menjadi salah satu satu faktor penyebab persebaran suatu penyakit karena kotoran manusia tersebut akan mencemari lingkungan sekitar. Penelitian ini bertujuan untuk mengetahui perbedaan faktor predisposisi yang terdiri dari sikap dan pengetahuan terhadap cara buang air besar pada kampung belum ODF dan kampung ODF di Surabaya. 


\section{METODE}

Penelitian ini merupakan penelitian observasional analitik. Desain penelitian ini yaitu cross sectional. Sifat penelitian ini yaitu membandingkan dengan mengumpulkan data tanpa adanya intervensi pada sampel yang terpilih dan dilakukan hanya sesaat di satu waktu untuk menggambarkan variabel penelitian ini dan memberikan informasi terkait situasi yang terjadi. Populasi penelitian ini yaitu seluruh masyarakat yang tinggal di pinggir rel kereta api pada kampung ODF di Ketintang dan kampung belum ODF di Kelurahan Jagir. Kampung belum ODF di Kelurahan Jagir terdiri dari tiga RT (5, 6, dan 7) pada RW 10 sebanyak 215 KK. Kampung ODF di Kelurahan Ketintang terdiri dari dua RT (7 dan 3) sebanyak 147 KK. Sampel dalam penelitian ini yaitu sebagian tiga RT (5, 6, dan 7) pada RW 10 sebanyak 215 KK. Kampung ODF di Kelurahan Ketintang terdiri dari 2 RT (7 dan 3) pada RW 3 sebanyak 147 KK. Sampel dalam penelitian ini yaitu sebagian penduduk yang tinggal di wilayah lokasi penelitian dan diwakilkan oleh salah satu dari anggota keluarga yang berusia minimal 17 tahun atau sudah memiliki Kartu Tanda Penduduk (KTP). Jumlah sampel dari hasil perhitungan menggunakan rumus Slovin yaitu sebanyak 68 sampel di kampung belum ODF dan 60 sampel di kampung ODF. Teknik sampling dalam penelitian ini yaitu proportional random sampling dengan menggunakan probability sampling.

Variabel bebas penelitian ini yaitu faktor predisposisi yang terdiri dari sikap dan pengetahuan. Variabel terikat dari penelitian ini yaitu cara buang air besar. Teknik pengumpulan data primer menggunakan kuesioner dan wawancara. Sebelum melakukan wawancara dan pengisian kuesioner, peneliti telah melakukan dan lolos uji etik yang dilakukan di Fakultas Kedokteran Gigi Universitas Airlangga dengan nomor sertifikat 109/HRECC.FODM/III/2020. Data penelitian yang didapat dijamin kerahasiaannya dengan adanya etik tersebut. Data sekunder menggunakan profil Kelurahan Jagir dan Kelurahan Ketintang. Hasil penelitian disajikan secara deskriptif dan berupa tabel. Analisis statistik atau uji bivariat menggunakan Mann-Whitney $U$ test untuk membandingkan variabel bebas dan variabel terikat penelitian ini.

\section{HASIL DAN PEMBAHASAN}

Kelurahan Jagir dalam penelitian ini sebagai kampung belum ODF. Kelurahan ini memiliki penduduk sebanyak 22.421 jiwa dengan $6.060 \mathrm{KK}$ berdasarkan profil kelurahan tahun 2019. Kepadatan penduduk khususnya di Kelurahan Jagir sekitar 22.160,22 jiwa $/ \mathrm{km}^{2}$. Penduduk di wilayah tersebut paling banyak berjenis kelamin perempuan yaitu 11.244 orang $(50,14 \%)$. Usia penduduk di Kelurahan Jagir paling banyak pada kategori 16-20 tahun yaitu sekitar 9,95\% dari total jumlah penduduk. Jenjang pendidikan yang paling banyak di dominasi pada jenjang SMA sebanyak 8.832 jiwa dari total jumlah penduduk. Penduduk Kelurahan Jagir sebanyak $27,01 \%$ atau 6.085 orang bekerja sebagai karyawan perusahaan. Wilayah Kelurahan Jagir dekat dengan sungai yang mana sebagian masyarakatnya ada yang tinggal disekitar sungai, sehingga dapat memungkinkan masyarakat melakukan buang air besar di sungai. Kelurahan Jagir wilayahnya dilintasi oleh rel kereta dan dekat dengan stasiun. Sebagian lainnya penduduk Kelurahan Jagir tinggal di pinggir rel kereta api. Status kepemilikan tanah yang ditinggali oleh penduduk tersebut yang berada di pinggir rel adalah milik dari PT Kereta Api Indonesia. Kelurahan Jagir merupakan salah satu wilayah yang buruk terkait akses jamban dan RW 10 merupakan wilayah di Kelurahan Jagir yang paling kumuh dan penduduknya masih banyak yang memiliki kebiasaan BABS.

Kelurahan Ketintang dalam penelitian ini sebagai kampung ODF. Lokasi penelitian di Kelurahan Ketintang jumlah penduduk seluruhnya sebanyak 17.371 orang dan sebanyak 5.483 KK berdasarkan profil tahun2019. Penduduk perempuan di Kelurahan Jagir sebanyak 50,85\% atau 8.833 orang. Kategori usia 3135 tahun mendominasi di wilayah tersebut yaitu sebanyak 13,60\% dari total jumlah penduduk. Jenjang pendidikan paling banyak yaitu sedang menempuh S1 sejumlah 2.521 jiwa. Penduduk dengan jenis pekerjaan paling banyak yaitu sebagai wiraswasta. Kelurahan Ketintang wilayahnya dilintasi oleh kereta api sebagian dan juga Kelurahan Ketintang juga di aliri oleh sungai. Kedua lokasi tersebut terdapat sebagian masyarakat Kelurahan Ketintang yang tinggal dipinggir rel kereta dan sungai. Hal tersebut dapat menumbuhkan potensi masyarakat untuk melakukan buang air besar yang tidak ditempatnya seperti di sungai. Kelurahan Ketintang sudah mengklaim wilayahnya sebagai wilayah ODF. Kelurahan tersebut memiliki kader terkait lingkungan hidup dan kebersihan, dan kader-kader yang berpartisipasi aktif untuk meningkatkan kebersihan di wilayah mereka. RW 3 merupakan salah satu RW yang letaknya dekat dengan rel kereta api dan sungai. Wilayah tersebut pernah mendapatkan sosialisasi terkait STBM sehingga masyarakatnya memiliki jamban yang sehat di masing-masing rumah.

Tabel 1 menunjukkan pada kampung belum ODF sebanyak 42 responden $(61,76 \%)$ memiliki kebiasaan cara buang air besar dengan kategori baik. Kampung ODF seluruhnya cara buang air besar sudah baik. 
Tabel 1. Distribusi Frekuensi Cara Buang Air Besar Masyarakat di Kampung Belum ODF dan Kampung ODFTahun 2020

\begin{tabular}{lcc}
\hline Cara Buang Air Besar & Frekuensi (n) & Persentase (\%) \\
\hline Kampung Belum ODF & & \\
Baik & 42 & 61,76 \\
Kurang & 26 & 38,24 \\
Kampung ODF & 60 & 100,00 \\
Baik & 0 & 0,00 \\
Kurang & & \\
\hline
\end{tabular}

Cara buang air besar pada kedua kelurahan dapat dilihat bahwa Kelurahan Jagir masih terdapat masyarakat yang memiliki kebiasaan BABS yang buruk. Masyarakat memiliki jamban akan tetapi kotoran dialirkan ke sungai yang dekat dengan pemukiman mereka atau saluran kotoran menuju tanah yang ada di bawahrumah. Masih ada masyarakat yang memiliki cara BABS sebanyak 38,24\% di kampung belum ODF. Peneliti pada saat melakukan turun lapangan, ditemukan jamban yang belum sehat di rumah warga pada kampung belum ODF. Suatu wilayah dapat mengklaim kampungnya ODF apabila wilayah mereka telah memenuhi syarat berdasarkan Peraturan Menteri Kesehatan Nomor 3 Tahun 2014 tentang STBM yang mana seluruh masyarakat di wilayahnya harus sudah memiliki kebiasaan buang air besar pada jamban yang sehat.

Sikap adalah respon yang masih tertutup dari individu terhadap suatu objek atau rangsangan sosial (Notoatmodjo, 2012). Sikap merupakan sindrom untuk merespons rangsangan dari luar atau objek, sehingga melibatkan perhatian, pikiran, perasaan, dan kejiwaan yang lainnya (Apriyanti, Widjanarko and Laksono, 2019). Sikap dalam diri seseorang tidak dapat terlihat secara langsung, akan tetapi terlebih dahulu harus dapat diartikan dari sikap tertutup tersebut. Sikap merupakan predisposisi dari perilaku seseorang sehingga sikap dianggap suatu kesiapan individu untuk bertindak terhadap objek yang ada di lingkungan sekitarnya. Sikap dari seseorang dapat terwujud apabila adanya dorongan dari orang sekitar (Samosir and Ramadhan, 2019). Sikap yang ditunjukkan seseorang akan dapat dipahami proses kesadarannya yang dapat menentukan tindakan yang akan dilakukan dalam kegiatan sosialnya (Qudsiyah, Pujiati and Ningrum, 2015).

Tabel 2 menunjukkan hasil uji perbedaan sikap pada kampung belum ODF dengan kampung ODF didapatkan nilai signifikansi $0,00(p<0,05)$ dengan uji Mann-Whitney $U$ test.. Uji tersebut memiliki arti bahwa adanya perbedaan sikap dengan praktik buang air besar pada kampung belum ODF dan kampung ODF.

Tabel 2. Hasil Uji Perbedaan Variabel Sikap Pada Kampung Belum ODF dan Kampung ODF Tahun 2020

\begin{tabular}{lcccc}
\hline \multirow{2}{*}{ Sikap } & \multicolumn{2}{c}{ Kampung Belum ODF } & \multicolumn{2}{c}{ Kampug ODF } \\
\cline { 2 - 5 } & $(\mathbf{n})$ & $(\boldsymbol{\%})$ & $(\mathbf{n})$ & $(\boldsymbol{\%})$ \\
\hline Baik & 30 & 44,11 & 53 & 88,33 \\
Cukup & 37 & 54,41 & 7 & 11,67 \\
Kurang & 1 & 1,48 & 0 & 0,00 \\
\hline Total & 68 & 100,00 & 60 & 100,00 \\
\hline
\end{tabular}

Penelitian ini sejalan dengan penelitian yang dilakukan di Semarang yang menunjukkan bahwa adanya hubungan sikap dengan status ODF. Nilai signifikansi penelitian tersebut yaitu $0,00(p<0,05)$. Hal tersebut dikarenakan rata-rata responden penelitian masih mempunyai sikap yang kurang baik dalam penggunaan jamban sehingga perilaku BAB yang dimiliki buruk (Sukma, Mursid and Nurjazuli, 2018). Hasil penelitian lain menunjukkan adanya hubungan antara sikap dengan perilaku BABS dengan nilai signifikansi sebesar 0,002 ( $p<0,05)$ (Hayana, Marlina and Kurnia, 2018). Penelitian tersebut menyatakan bahwa sikap negatif dari seseorang memiliki risiko 1,9 kali memiliki kebiasaan BABS dibanding orang yang bersikap positif.

Sikap seseorang yang masih belum dianggap baik, maka rentan bagi orang tersebut untuk tetap berperilaku BABS (Zahtamal et al., 2020). Sikap seseorang dapat dipengaruhi beberapa faktor seperti adanya pengaruh dari tetangga untuk tidak melakukan BABS sehingga dapat menumbuhkan kebiasaan baru karena kesan yang ditinggalkan kuat. Selain itu sikap juga dipengaruhi oleh lembaga, media massa, dan faktor emosional. Faktor emosional merupakan sesuatu yang didasari dengan emosi individu dalam menentukan sikap dan mempertahankan ego (Marwanto, Netrianis and Mualim, 2019). 
Pengetahuan merupakan suatu hasil dari proses seseorang mengamati suatu objek tertentu(Apriyanti, Widjanarko and Laksono, 2019). Pengetahuan merupakan suatu komponen yang sangat penting dalam menentukan suatu tindakan seseorang. Pengetahuan yang kurang atau minim dapat mempengaruhi seseorang dalam menentukan keputusan masalah yang dihadapinya, sehingga sulit untuk menghadapi masalah. Seseorang harus memiliki pengetahuan terlebih dahulu sebelum melakukan tindakan (Notoatmodjo, 2014). Pengetahuan yang dimiliki individu apabila semakin tinggi atau banyak, maka seseorang tersebut akan semakin bagus dalam memanfaatkan jamban, begitu pula sebaliknya (Anggoro and Ningrum, 2015). Pengetahuan yang belum ideal atau belum berada pada kategori baik, dapat menyebabkan kerentanan masyarakat untuk tetap melakukan BABS (Zahtamal et al., 2020). Pengetahuan yang baik jika tidak didukung dengan faktor lain seperti adanya ketersediaan lahan, pendapatan yang cukup, air bersih, dan peran tenaga kesehatan maka masyarakat tidak akan membuat jamban sendiri di rumah mereka sehingga tidak bisa menimbulkan kebiasaan buang air besar yang baik(Arlin, Sudirman and Afni, 2018).

Hasil penelitian tabel 3 nilai signifikansi dari uji analisis yaitu sebesar $0,00(p<0,05)$. Dapat dilihat bahwa masyarakat di Kelurahan Jagir paling banyak dengan kategori pengetahuan cukup, sedangkan di Kelurahan Ketintang didominasi dengan kategori baik. Data yang didapatkan mayoritas masyarakat Kelurahan Jagir tidak dapat menjawab pertanyaan singkatan dari STBM, berapa jumlah pilar STBM, dan penyakit apa saja yang dapat menular jika melakukan BABS. Masyarakat di Kelurahan Ketintang mayoritas tidak dapat menjawab terkait pertanyaan penyakit menular akibat perilaku BABS. Peneliti melakukan wawancara dengan ketua RW 3 di Kelurahan Ketintang dan didapatkan informasi bahwa pernah dilakukannya sosialisasi mengenai STBM pilar 1. Peserta dari sosialisasi tersebut yaitu tiap ketua RW dan RT di Kelurahan Ketintang. Program tersebut yaitu CSR PT PJB mengenai STBM "Jamban Sehat". Hasil dari sosialisasi tersebut disampaikan ke setiap warga di tiap RT melalui ketua RW dan RT masing-masing. Kegiatan sosialisasi STBM pilar 1di Kelurahan Jagir pernah dilakukan. Peserta pada sosialisasi di Kelurahan Jagir hanya dihadiri oleh ketua RW wilayah tersebut. Hal tersebut yang mempengaruhi pengetahuan terkait STBM pilar 1 di Kelurahan Jagir masih kurang.

Tabel 3. Hasil Uji Perbedaan Variabel Pengetahuan Pada Kampung Belum ODF dan Kampung ODF Tahun 2020

\begin{tabular}{|c|c|c|c|c|}
\hline \multirow{2}{*}{ Pengetahuan } & \multicolumn{2}{|c|}{ Kampung Belum ODF } & \multicolumn{2}{|c|}{ Kampung ODF } \\
\hline & (n) & $(\%)$ & (n) & $(\%)$ \\
\hline Baik & 7 & 10,31 & 29 & 48,33 \\
\hline Cukup & 47 & 69,11 & 27 & 45,00 \\
\hline Kurang & 14 & 20,58 & 4 & 6,67 \\
\hline Total & 68 & 100,00 & 60 & 100,00 \\
\hline \multicolumn{5}{|c|}{$p$-value $=0,00(<0,001)$} \\
\hline
\end{tabular}

Hasil yang didapatkan dari penelitian ini sama seperti yang dilakukan di Kabupaten Pemalang, bahwa terdapat hubungan pengetahuan dengan perilaku BAB di jamban dengan nilai $p$ sebesar 0,002 $(p<0,05)$. Hal tersebut dikarenakan responden penetian masih memiliki pengetahuan yang kurang terkait BAB di jamban dan memiliki kebiasaan kurang baik terkait BAB di jamban begitu pula sebaliknya (WIjayanti, Widagdo and Shaluhiyah, 2016). Penelitian ini juga sama seperti yang dilakukan di Desa Sumbersari, bahwa ada hubungan pengetahuan dengan perilaku stop BABS. Nilai signifikan penelitian tersebut yaitu $0,001(p<0,05)$. Hal tersebut dikarenakan masih banyak masyarakat yang belum memiliki pengetahuan dampak jika melakukan BABS (Febriani, Samino and Sari, 2016). Penelitian lain yang dilakukan di Kecamatan Gunungpati Semarang, didapatkan bahwa masyarakatnya rata-rata pengetahuannya sudah baik namun pengetahuan yang dimiliki terkait pentingnya buang air besar di jamban dan dampak jika melakukan BABS dapat menimbulkan penyakit menular masih belum sempurna. Hal tersebut dapat mempengaruhi pemanfaatan jamban yang baik (Oktanasari, Laksono and Indriyanti, 2018).

\section{KESIMPULAN}

Hasil dari penelitian ini dapat disimpulkan bahwa adanya perbedaan sikap terhadap cara buang air besar masyarakat pada kampung belum ODF dan kampung ODF. Pengetahuan masyarakat terdapat perbedaan terhadap cara buang air besar pada kampung belum ODF dan kampung ODF. Sikap yang baik dari masyarakat dapat menumbuhkan cara buang air besar yang baik pula. Sikap yang baik dari seseorang timbul karena memiliki pengetahuan yang baik, apabila pengetahuan masyarakat tinggi maka dapat mempengaruhi cara buang air besar yang baik.

Saran dari penelitian ini yaitu mengadakan penyuluhan terkait informasi cara buang air besar yang baik sehingga dapat meningkatkan pengetahuan dan sikap menerapkan cara buang air besar yang baik terutama masyarakat di kampung belum ODF. Saran untuk penelitian selanjutnya untuk meneliti faktorfaktor lainnya yang menjadi pembeda pada kampung belum ODF dan kampung ODF. 


\section{ACKNOWLEDGEMENT}

Peneliti berterimakasih kepada Badan Kesatuan Bangsa, Politik dan Perlindungan Masyarakat Kota Surabaya, Dinas Kesehatan Kota Surabaya, Kecamatan Wonokromo dan Kecamatan Gayungan, Kelurahan Jagir dan Kelurahan Ketintang, Ketua RW dan RT Kelurahan Jagir dan Kelurahan Ketintang, serta masyarakat Kelurahan Jagir dan Kelurahan Ketintang yang telah meluangkan waktunya dan berpartisipasi dalam penelitian ini sehingga penelitian ini dapat terlaksana sesuai dengan harapan.

\section{REFERENSI}

Anggoro, F. F. and Ningrum, P. T. (2015) 'Analisis Faktor yang Berhubungan dengan Pemanfaatan Jamban Di Kawasan Perkebunan Kopi ( Analysis of Factors Associated with the Use of Toilets At Coffee Plantation Region )', e-Jurnal Pustaka Kesehatan, 3(1), pp. 171-178.

Apriyanti, L., Widjanarko, B. and Laksono, B. (2019) 'Faktor-faktor yang Mempengaruhi Pemanfaatan Jamban Keluarga di Kecamatan Jatibarang Kabupaten Brebes', Jurnal Promosi Kesehatan Indonesia, 14(1), p. 1. doi: 10.14710/jpki.14.1.1-14.

Arlin, Sudirman and Afni, N. (2018) 'Faktor Yang Berhubungan dengan Kepemilikan Jamban di Desa Ta'aniuge Kecamatan Tomini Kabupaten Parigi Moutong', Jurnal Kolaboratif Sains, 1(1), pp. 299- 312. doi: 10.31934/jom.v1i1.362.

Febriani, W., Samino and Sari, N. (2016) 'Faktor Yang Mempengaruhi Perubahan Perilaku Stop BuangAir Besar Sembarangan (BABS)', Jurnal Dunia Kesmas, 5(3), pp. 121-130.

Hayana, Marlina, H. and Kurnia, A. (2018) 'Hubungan Karakteristik Individu dan Lingkungan SosialTerhadap Perilaku Buang AirBesarSembarang', Jurnal Kesehatan Komunitas, 4(1), pp. 815.

Kemenkes (2019) STBM (Sanitasi Total Berbasis Masyarakat).

Kementerian Kesehatan RI Badan Penelitian dan Pengembangan (2018) Hasil Utama Riset Kesehatan Dasar, Kementrian Kesehatan Republik Indonesia.

Marwanto, A., Netrianis and Mualim (2019) 'Hubungan Tingkat Pengetahuan dan Sikap dengan Pelaksanaan Sanitasi Total Berbasis Masyarakat (STBM) Pilar Pertama di Wilayah Kerja UPTD Puskesmas Perawatan Ratu Agung Kelurahan Pematang Gubernur Kota Bengkulu', Journal of Nursing and Public Health, 7(1), pp. 1-6.

Notoatmodjo, S. (2012) Promosi Kesehatan dan Perilaku Kesehatan (edisi revisi 2012), Jakarta: rineka cipta.

Notoatmodjo, S. (2014) Ilmu Perilaku Kesehatan, Jakarta: rineka cipta.

Oktanasari, W., Laksono, B. and Indriyanti, D. R. (2018) 'Faktor Determinan dan Respon Masyarakat Terhadap Pemanfaatan Jamban dalam Program Katajaga di Kecamatan Gunungpati Semarang', Public Health Perspective Journal, 2(3), pp. 279-286.

Qudsiyah, W. A., Pujiati, R. S. and Ningrum, P. T. (2015) 'Faktor-faktor yang berhubungan dengan Tingginya angka open defecation ( OD ) di kabupaten Jember ( studi di desa Sumber Kalong kecamatanKalisat )', e-Jurnal Pustaka Kesehatan, 3(2), pp. 362-369.

Samosir, K. and Ramadhan, F. S. (2019) 'Peranan Perilaku dan Dukungan Tokoh Masyarakat terhadap Kepemilikan Jamban Sehat di Tanjungpinang', Jurnal Kesehatan, 12(1), pp. 168-174.

Sukma, H., Mursid and Nurjazuli (2018) 'Hubungan Pengetahuan, Sikap BAB, dan Kepemilikan Septic Tank Dengan Status ODF (Open Defecation Free) di Kecamatan Candisari Kota Semarang', Jurnal Kesehatan Masyarakat (e-Journal), 6(6), pp. 143-149.

Syam, D. M. (2020) 'Pengetahuan dan Sikap Dalam Pelaksanaan Sanitasi Total Berbasis Masyarakat (STBM) di Kabupaten Donggala’, Poltekita: Jurnal Ilmu Kesehatan, 14(1), pp. 82-88.

WHO and UNICEF (2017) Progress on Drinking Water, Sanitation and Hygiene: 2017 Update and SDG Baseline, World Health Organization. doi: 10.1016/j.pnpbp.2017.06.016.

Widowati, N. N. (2015) 'Hubungan Karakteristik Pemilik Rumah dengan Perilaku Buang Air Besar Sembarangan (BABS) di Wilayah Kerja Puskesmas Sambungmacan II Kabupaten Sragen', Skripsi, pp. 1-19.

WIjayanti, A. K., Widagdo, L. and Shaluhiyah, Z. (2016) 'Faktor-Faktor Yang Berhubungan Dengan Buang Air Besar di Jamban di Desa Gunungsari Kecamatan Pulosari Kabupaten Pemalang', 4(1), pp. $450-460$.

Zahtamal, Z. et al. (2020) 'Defecation Behavior in Elementary School Age Children Who Live Along the Kampar River Riau Province', Jurnal Kesehatan Lingkungan, 12(2), p. 87. doi: 10.20473/jkl.v12i2.2020.87-96. 